\title{
Estimation of phylogenetic relationships of Phlomis species based on seed protein polymorphism
}

\author{
Ertuğrul Yüzbaşığlu* \\ Department of Biology \\ Faculty of Arts and Sciences \\ Erciyes University \\ Kayseri 38039, Turkey \\ Tel: 903524374937 Ext. 33062 \\ Fax: 903524374933 \\ E-mail: yuzbasie@erciyes.edu.tr
Department of Biology
Faculty of Arts and Sciences
Erciyes University
Kayseri 38039, Turkey \\ Mehmet Yaşar Dadand

\section{Servet Özcan} \\ Department of Biology \\ Faculty of Arts and Sciences \\ Erciyes University \\ Kayseri 38039, Turkey \\ Website: http://www.erciyes.edu.tr
}

Keywords: Phlomis, Phlomoides, Phlomis taxa, SDS-PAGE, seed proteins.

\author{
Abbreviations: DTT: dithiothreitol \\ RAPDs: randomly amplified polymorphic DNA \\ SDS-PAGE: sodium dodecyl sulphate polyacrylamide gel electrophoresis \\ TES: TE-saline \\ UPGMA: unweighted pair-group method with arithmetic averages
}

In this study, phylogenetic relationships among 39 Phlomis taxa were investigated based on seed protein profiles produced by sodium dodecyl sulphate polyacrylamide gel electrophoresis (SDS-PAGE). A total of 21 polypeptide bands were scored, of which, 19 were polymorphic among the taxa of the genus Phlomis. A distance matrix was generated from the similarity matrix which was computed by using Jaccard's similarity coefficients, based on polymorphic bands and then an UPGMA tree was established through cluster analysis performed on the distance matrix. Genetic distances ranged from 0.00 to 0.50 within subsection Dendrophlomis; from 0.00 to 0.625 within subsection Gymnophlomis and from 0.00 to 0.769 within subsection Oxyphlomis. The UPGMA tree formed four groups. The topology of the tree is in agreement with the taxonomic view regarding the section Phlomis as it is divided into three subsections as Dendrophlomis, Gymnophlomis and Oxyphlomis based on morphological characters. The grouping pattern of the tree also indicated that subsection Dendrophlomis is more closely related to subsection Gymnophlomis than subsection Oxyphlomis.
The genus Phlomis L. contains over 100 species that have been divided into two main sections: Phlomoides and Phlomis (Moench, 1794; Albaladejo et al. 2005). Section Phlomis was further subdivided into three subsections, Dendrophlomis, Gymnophlomis and Oxyphlomis (Bentham, 1834). The diagnostic character for separating sections is corolla shape. Species of section Phlomis, which have corolla with curved upper lip and trifid lower lip with large median and smaller lateral lobes, differs from species of section Phlomoides that have corolla with straight upper lip and trifid lower lip with sub equal lobes (Azizian and Moore, 1982). Section Phlomis occurs mostly in the Mediterranean region, where Turkey is regarded as one of the primary center of diversification for species of the section (Hedge, 1986). For instance, in the Flora of Turkey, the genus Phlomis consists of 34 species and six varieties, of which 22 are endemic to that flora (Huber-Morath, 1982).

Taxonomic relationships among species of the genus Phlomis have been assessed by morphological characters (Azizian and Moore, 1982; Huber-Morath, 1982; Taylor,

*Corresponding author 


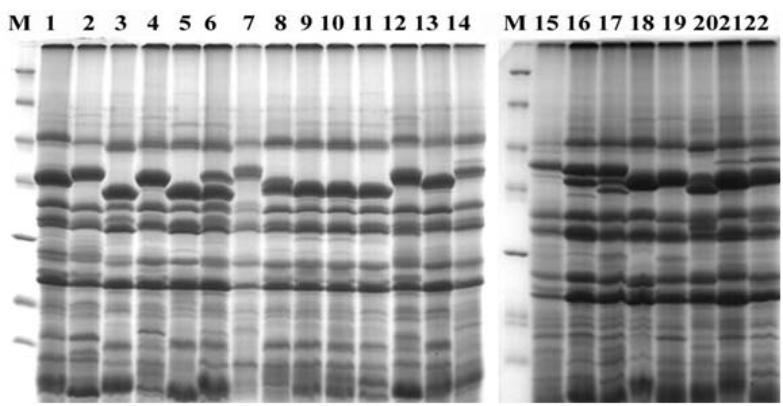

Figure 1. Seed protein profiles of 39 Phlomis taxa $(M=$ size marker; numbers 1-22 as in Table 1).

1998). Nevertheless, based on morphological characters alone, it is difficult to distinguish $P$. armeniaca, $P$. sieheana, $P$. sintenisii, $P$. lanceolata and $P$. carica from each other within subsection Gymnophlomis because they have overlapping variations in terms of the major delimiting morphological characters such as plant height, basal leaves sizes and shapes, bracteol length, calyx teeth shape and length, indumentum of calyx and number of flowers per verticillaster (Huber-Morath, 1982). Morever, differentiation of $P$. carica from $P$. armeniaca, and of $P$. nissoli from $P$. syriaca within this complex is based on indimentum of calyces and leaves; hovewer, this character shows high variation among individuals of a population and among populations of these species (Huber-Morath, 1982). Also, hybridization is a common incident in this genus, leading to the formation of many interspecific hybrids that increase the taxonomic complexity (Albaladejo et al. 2004; Albaladejo et al. 2005; Albaladejo and Aparicio, 2007; Yuzbasioglu et al. 2008b). Seed storage protein markers have been sucessfully used to resolve taxonomic relationships and characterize cultivated varieties in a number of crop plant species (Igrejas et al. 1999; Vladova et al. 2000; Jha and Ohri, 2002; Karihaloo et al. 2002; Syros et al. 2003; Bhargava et al. 2005; Cherdouh et al. 2005; Alvarez et al. 2006; Stoilova et al. 2006; Mirali et al. 2007; Rout and Chrungoo, 2007; Yuzbasioglu et al. 2008a) because they are stable, uniform, reliable, reproducible and largely independent of environmental fluctuations (Ghafoor et al. 2002; Panigrahi et al. 2007). The taxonomic relationships among species of Phlomis based on seed protein electrophoresis have not been studied so far. The objective of the present study was to assess taxonomical relationships among 39 Phlomis taxa based on sodium dodecyl sulphate polyacrylamide gel electrophoresis (SDSPAGE) of seed proteins.

\section{MATERIALS AND METHODS}

Seeds from 39 Phlomis taxa examined in the present study were collected from different parts of Turkey (Table 1). Seeds from each taxon were collected from at least 10 single plants within a population of that taxon and then the seeds of each taxon were bulked. The bulked seeds of each taxon were ground into a fine powder with liquid nitrogen. $25 \mathrm{mg}$ of flour samples were transferred into $200 \mu \mathrm{L}$ of TESaline (TES) buffer within $1.5 \mathrm{ml}$ eppendorf tubes containing $100 \mathrm{mM}$ Tris $\mathrm{HCl}, 50 \mathrm{mM} \mathrm{NaCl}, 1 \mathrm{mM}$ EDTA, 2\% SDS, 2\% PVP, $100 \mu \mathrm{M} \quad \mathrm{N} \alpha-\mathrm{P}-$ Tosyl-L-Lysine Chloromethyl Ketone (TLCK), $0.3 \mu \mathrm{M}$ Phenylmethanesulphonyl Fluoride (PMSF) and $100 \mathrm{mM}$ Phenylalanine Ketone (TPCK). The flour samples were mixed with the TES buffer by vortexing for $10 \mathrm{~min}$ at room temperature. Then the mixture was heated for $3 \mathrm{~min}$ at between 80 and $90^{\circ} \mathrm{C}$. After cooling at room temperature, 4 $\mu \mathrm{L}$ of DTT (dithiothreitol) solution (3.25 M DTT in $\mathrm{dH}_{2} \mathrm{O}$ ) was added to the mixture. Having centrifugated the tubes at $15000 \times \mathrm{g}$ for $15 \mathrm{~min}$ at $4^{\circ} \mathrm{C}$ by using a 3K30 cooling centrifuge, the spernatant was transferred into new tubes. Then protein content of each sample was determined according to the modified Bradford assays described by Ramagli and Rodriguez (1985) using Bovine Serum Albumin (BSA) faction as the standard. The protein concentration of each sample was equalized by TES buffer and the equalized protein concentration was either mixed in half with loading buffer ( $65 \mathrm{mM}$ Tris $\mathrm{HCl}, \mathrm{pH} 6.8,1 \%$ SDS, 2\% 2-mercaptoethanol, 20\% Glycerol) or kept on ice and stored at $-20^{\circ} \mathrm{C}$ for further use.

Protein patterns were analyzed by $14 \%$ SDS-PAGE (18 x 20 x $0.1 \mathrm{~cm}$; vertical slab gels; Protean Xii, BioRad, CA, USA) according to Laemmli (1970). The molecular weights of the dissociated polypeptides were determined by using molecular size markers in the range between 14.4 and 116 $\mathrm{kD}$ (Fermentas SMO431). Gels were stained by a sensitive colloidal Coomassie Brillant Blue G-250 as described by Olivieri et al. (2001) and photographed using a digital image analysis system (Vilber-Lourmat, Bio-Gene V.99). A similarity matrix based on Jaccard's similarity coefficient was produced with NTSYS-pc (Rohlf, 1992) from protein bands scored as 0 (absent) and 1 (present) and then, a distance matrix was constructed by subtracting the similarity coefficients from 1 . A dendrogram based on the distance matrix was produced using the unweighted pair-

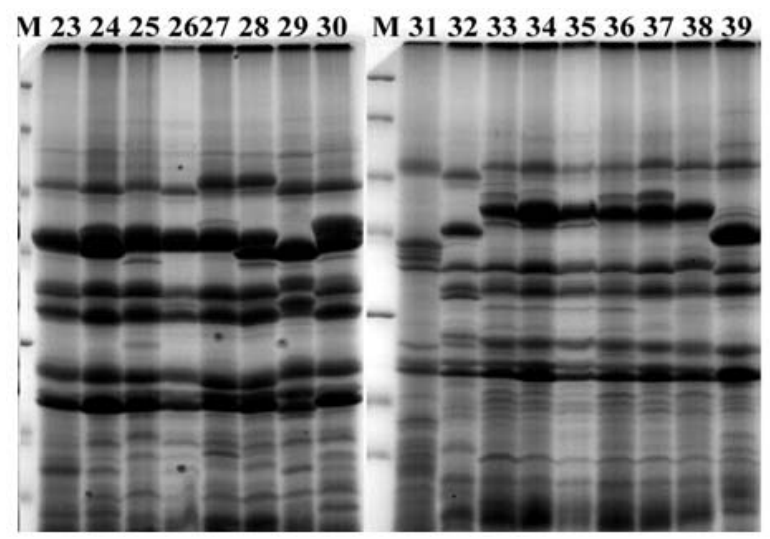

Figure 2. Seed protein profiles of 39 Phlomis taxa $(M=$ size marker; numbers 23-39 as in Table 1). 
Table 1. Phlomis material and its source.

\begin{tabular}{|c|c|c|c|c|c|}
\hline Numbers & $\begin{array}{l}\text { Collector } \\
\text { Number }\end{array}$ & Phlomis taxa & Collection site & $\begin{array}{l}\text { Altitude } \\
\text { (m) }\end{array}$ & Date \\
\hline 1 & MYD 1718 & P. russeliana (Sims) Bentham & Bolu; Around Abant Lake. & 1220 & 12 viii 1999 \\
\hline 2 & MYD 1451 & P. fruticosa $\mathrm{L}$. & Izmir; Cesme, Ciftlikkoy. & $60-70$ & 27 iv 2000 \\
\hline 3 & MYD 1102 & P. Iunariifolia Sm. & $\begin{array}{l}\text { Antalya; Alanya, East slopes of } \\
\text { Kaledran stream. }\end{array}$ & 50 & 25 vi 1998 \\
\hline 4 & MYD 1166 & $\begin{array}{l}\text { P. grandiflora var. grandiflora } \\
\text { H.S.Thompson }\end{array}$ & $\begin{array}{l}\text { Antalya; Kas-Elmali road. Oluk Yaylasi, } \\
\text { between Gomuce and Kuruova villages. }\end{array}$ & 1700 & 28 vi 1998 \\
\hline 5 & MYD 1103 & P. grandiflora var. fimbrilligera Hub.-Mor. & $\begin{array}{l}\text { Antalya; Alanya, West slopes of } \\
\text { Kaledran stream. }\end{array}$ & 60 & 25 vi 1998 \\
\hline 6 & MYD 1190 & P. viscosa Poiret & $\begin{array}{l}\text { Osmaniye; Osmaniye-Yarpuz Yaylasi } \\
\text { road. }\end{array}$ & 550 & 6 viii 1998 \\
\hline 7 & MYD 1678 & P. bourgaei Boiss. & Antalya; Kemer, around Agva stream. & 60 & 4 vii 2003 \\
\hline 8 & MYD 1100 & P. leucophracta P.H. Davis \& Hub.-Mor. & $\begin{array}{l}\text { Antalya; Between Anamur-Alanya, } \\
\text { around Tenzile village. }\end{array}$ & 150 & 25 vi 1998 \\
\hline 9 & MYD 1065 & P.longifolia var. longifolia Boiss. \& BI. & Hatay; Between Gedik and Atik. & 800 & 13 vi 1998 \\
\hline 10 & MYD 1075 & $\begin{array}{l}\text { P.longifolia var. bailanica (Vierh.) Hub.- } \\
\text { Mor. }\end{array}$ & Hatay; Above Guzelyayla (Sogukoluk). & 980 & 15 vi 1998 \\
\hline 11 & MYD 1158 & P. amanica Vierh. & $\begin{array}{l}\text { Hatay; Arsuz (Ulucinar), Haymaseki } \\
\text { village, around Aktepe. }\end{array}$ & $250-300$ & 9 viii 1998 \\
\hline 12 & HD 6253 & P. lycia D. Don & Antalya; Termessos National Park. & $300-400$ & 22 vii 1996 \\
\hline 13 & MYD 1096 & P. monocephala P.H. Davis & $\begin{array}{l}\text { İçel; Between Kazanci-Anamur, around } \\
\text { Abanoz Yaylasi. }\end{array}$ & 1400 & 25 vi 1998 \\
\hline 14 & HD 6643 & P. chimerae Boissieu & Antalya; Kemer, around Cirali. & $20-50$ & $15 \vee 1998$ \\
\hline 15 & MYD 1029 & P. oppositiflora Boiss. \& Haussk. & Sivas; Between Darende-Gurun. & 1390 & 8 viii 1997 \\
\hline 16 & MYD 1287 & P. bruguieri Desf. & Gaziantep; Soft Dagi. & $\begin{array}{l}1350- \\
1460\end{array}$ & 16 vi 1999 \\
\hline 17 & MYD 1349 & P. armeniaca Willd. & $\begin{array}{l}\text { Tokat; Turhal, East slopes of Hastahane } \\
\text { hill. }\end{array}$ & 650 & 3 vii 1999 \\
\hline 18 & MYD 1384 & P. physocalyxHub.-Mor. & Sivas; Gurun-Kayseri 23 km. & 1600 & 11 vii 1999 \\
\hline 19 & MYD 1251 & P. angustissima Hub.-Mor. & Afyon; Dirmil; Dirmil pass. & 1580 & 9 vi 1999 \\
\hline 20 & MYD 1716 & P. capitata Boiss. & Malatya; Venk village. & 1195 & 12 vii 2003 \\
\hline 21 & MYD 1178 & P. kotschyana Hub.-Mor. & $\begin{array}{l}\text { Hatay; Arsuz, Haymaseki village, around } \\
\text { Aktepe. }\end{array}$ & $250-300$ & $19 \vee 1999$ \\
\hline 22 & MYD 1463 & P. sieheana Rech. & Kayseri; Gesi, around Ildem Koop. & c. 1150 & 28 vi 2000 \\
\hline 23 & MYD 1405 & P. sintenisii Rech. & Elazig; Around Harput Castle. & 1500 & 12 vii 1999 \\
\hline 24 & MYD 1436 & P. lanceolata Boiss. \& Hohen. & Van; Van-Gurpinar 11 km, Karabas & 2225 & 20 vii 1999 \\
\hline
\end{tabular}




\begin{tabular}{|c|c|c|c|c|c|}
\hline 25 & MYD 1352 & P. linearis Boiss. \& Bal. & $\begin{array}{l}\text { Kayseri; Develi-Kayseri } 12 \text { km (Erciyes } \\
\text { road). }\end{array}$ & 1930 & 9 vii 1999 \\
\hline 26 & MYD 1296 & P. brunneogaleata Hub.-Mor. & Gaziantep; Soft Dagi. & \begin{tabular}{|l}
$1350-$ \\
1460
\end{tabular} & 16 vi 1999 \\
\hline 27 & MYD 1086 & P. nissolii L. & $\begin{array}{l}\text { Nigde; Bor-Aksaray road, between } \\
\text { Yesilyurt- Altunhisar villages. }\end{array}$ & 1100 & 24 vi 1998 \\
\hline 28 & MYD 1063 & P. syriaca Boiss. & Adana; Ceyhan, Yilankale. & $100-300$ & 12 vi 1998 \\
\hline 29 & MYD 1036 & P. kurdica Rech. & $\begin{array}{l}\text { Kahramanmaras; Elbistan-Goksun } 13 \\
\text { km (old road). }\end{array}$ & 1140 & 7 viii 1997 \\
\hline 30 & MYD 1125 & P. carica Rech. & $\begin{array}{l}\text { Denizli; Acipayam, Alaattin town, } \\
\text { Degirmendere site. }\end{array}$ & 1100 & 28 vi 1998 \\
\hline 31 & MYD 1055 & P. tuberosa L. & Sivas; Imranlı-Zara 10 km. & 1350 & 16 viii 1997 \\
\hline 32 & MYD 1163 & P. samia L. & Adana; Gulek village-Adana $1 \mathrm{~km}$. & 1100 & 5 vii 1998 \\
\hline 33 & MYD 1321 & P. punges var. pungens Willd. & Kayseri; Yahyali-Maden road 14 km. & 1490 & 27 vi 1999 \\
\hline 34 & MYD 1057 & P. punges var. laxiflora Velen. & $\begin{array}{l}\text { B4 Ankara; Hacettepe university } \\
\text { Beytepe campus. }\end{array}$ & $\begin{array}{l}1050- \\
1200\end{array}$ & 19 viii 1997 \\
\hline 35 & MYD 1034 & P. punges var. hirta Velen. & Kahramanmaras; Cardak-Elbistan 5 km. & 1240 & 7 viii 1997 \\
\hline 36 & MYD 1320 & P. punges var. hispida Hub.-Mor. & Kayseri; Yahyali-Maden road $14 \mathrm{~km}$. & 1490 & 27 vi 1999 \\
\hline 37 & MYD 1429 & P. punges var. seticalycina Nab. & Van; Gurpınar-Catak 25 km. & 2090 & 20 vii 1999 \\
\hline 38 & MYD 1025 & P. integrifolia Hub.-Mor. & $\begin{array}{l}\text { Malatya; Malatya-Arapkir } 30 \mathrm{~km} \text {, around } \\
\text { Kuruçay. }\end{array}$ & 770 & 7 viii 1997 \\
\hline 39 & MYD 1038 & P. rigida Labill. & Malatya; Elbistan-Malatya 53 km. & 1600 & 7 viii 1997 \\
\hline
\end{tabular}

group method with arithmetic averages (UPGMA) under the NJ subprogram in the PHYLIP software package version 3.6a3 (Felsenstein, 2002).

\section{RESULTS AND DISCUSSION}

Seed storage proteins of the 39 Phlomis taxa examined by SDS-PAGE in the present study produced reproducible and stable protein bands that were used for the classification of the taxa studied in the genus (Figure 1 and Figure 2). A total of 21 polypeptide bands were scored, of which, 2 were universally present and 19 were polymorphic. The cluster analysis of the taxa based on distance matrix produced from Jaccard's coefficient was represented by an UPGMA dendrogram in Figure 3. The dendrogram formed four groups. The first group consisted of taxa from section Phlomis subsection Dendrophlomis: P. russeliana, P. lycia, P. fruticosa, P. grandiflora var. grandiflora, P. bourgaei, $P$. chimerae, $P$. lunariifolia, $P$. viscosa, $P$. grandiflora var. fimbrilligera, P. longifolia var. longifolia, P. longifolia var. bailanica, $P$. amanica, $P$. monocephala and $P$. leucophracta. Except for P. russeliana, a perennial herb, all other taxa within this subsection are shrubs. In species of this subsection, verticillasters generally have 12-20 flowers and the number of verticillasters range between 1 and 3 . In species of this subsection, bracteoles are linear-subulate to lanceolate and ovate in shape, generally 10-18 $\mathrm{mm}$ in length and the number of bracteoles is generally between 15 and 30. Relationships among P. viscosa, P. lunariifolia, $P$. grandiflora var. fimbrilligera, $P$. longifolia var. longifolia, $P$. amanica and $P$. monocephala obtained by SDS-PAGE analysis in the present study were generally in agreement with the previous study of relationships among species of Dendrophlomis, based on randomly amplified polymorphic DNA (RAPDs) markers (Yuzbasioglu and Dadandi, 2008). Nevertheless, different groupings were observed among $P$. bourgaei, $P$. leucophracta, $P$. chimerae and $P$. lycia when compared with the findings of the previous study, which excluded samples of $P$. russeliana, $P$. fruticosa and $P$. longifolia var. bailanica. Based on previous RAPD analysis, the grouping of these four taxa agrees better with the traditional taxonomic classification than grouping them based on SDS-PAGE analysis. SDSPAGE clustering of the species of subsection Dendrophlomis into two groups is consistent with the groupings of the previous RAPD study. However, $P$. leucophracta and $P$. chimerae were not clustered in the same group. In contrast, the finding from previous RAPD 
Estimation of phylogenetic relationships of Phlomis species based on seed protein polymorphism

Table 2. Genetic distances (as percentages) among 39 Phlomis taxa in the genus Phlomis (The numbers 1-39 refer to Table 1).

\begin{tabular}{|l|l|l|l|l|l|}
\hline 1 & 23 & 4 & 5
\end{tabular}

study placed both $P$. leucophracta and $P$. chimerae in one group and the rest of the species of Dendrophlomis into another group. P. longifolia var. longifolia, P. longifolia var. bailanica and $P$. amanica displayed the same protein pattern based on genetic distances obtained from SDSPAGE analysis. Morphologically, they are similar to each other in terms of the absence of glandular hairs. The highest genetic distance within subsection Dendrophlomis was observed between $P$. bourgaei and $P$. lunariifolia with a genetic distance value of 0.50 in the present analysis (Table 2). P. bourgaei has glandular hairs especially on the floral region (calyx and bracteoles) while $P$. lunariifolia is eglandular. Bracteoles are 10-24 mm in length and 0.75-1.5 $\mathrm{mm}$ in width in $P$. bourgaei and 7-15 $\mathrm{mm}$ in length and 2-
$3.5 \mathrm{~mm}$ in width in $P$. lunariifolia. Calyx teeth lengths are between 3-9 $\mathrm{mm}$ in $P$. bourgaei and $2-5 \mathrm{~mm}$ in $P$. lunariifolia. The range of genetic distances computed from the present study is concordant with the range (0.1450.495) obtained from our previous RAPD analysis, however, the lowest genetic distances found between $P$. amanica and $P$. monocephala and the highest between $P$. chimerae and $P$. lunariifolia in the previous study. Differences observed in the groupings of the taxa of subsection Dendrophlomis in the dendrograms obtained from SDS-PAGE analysis and the previous RAPD study could be caused by several reasons. For instance, seed proteins are coded by several homologous multigene families (Panigrahi et al. 2007), but RAPD bands may 


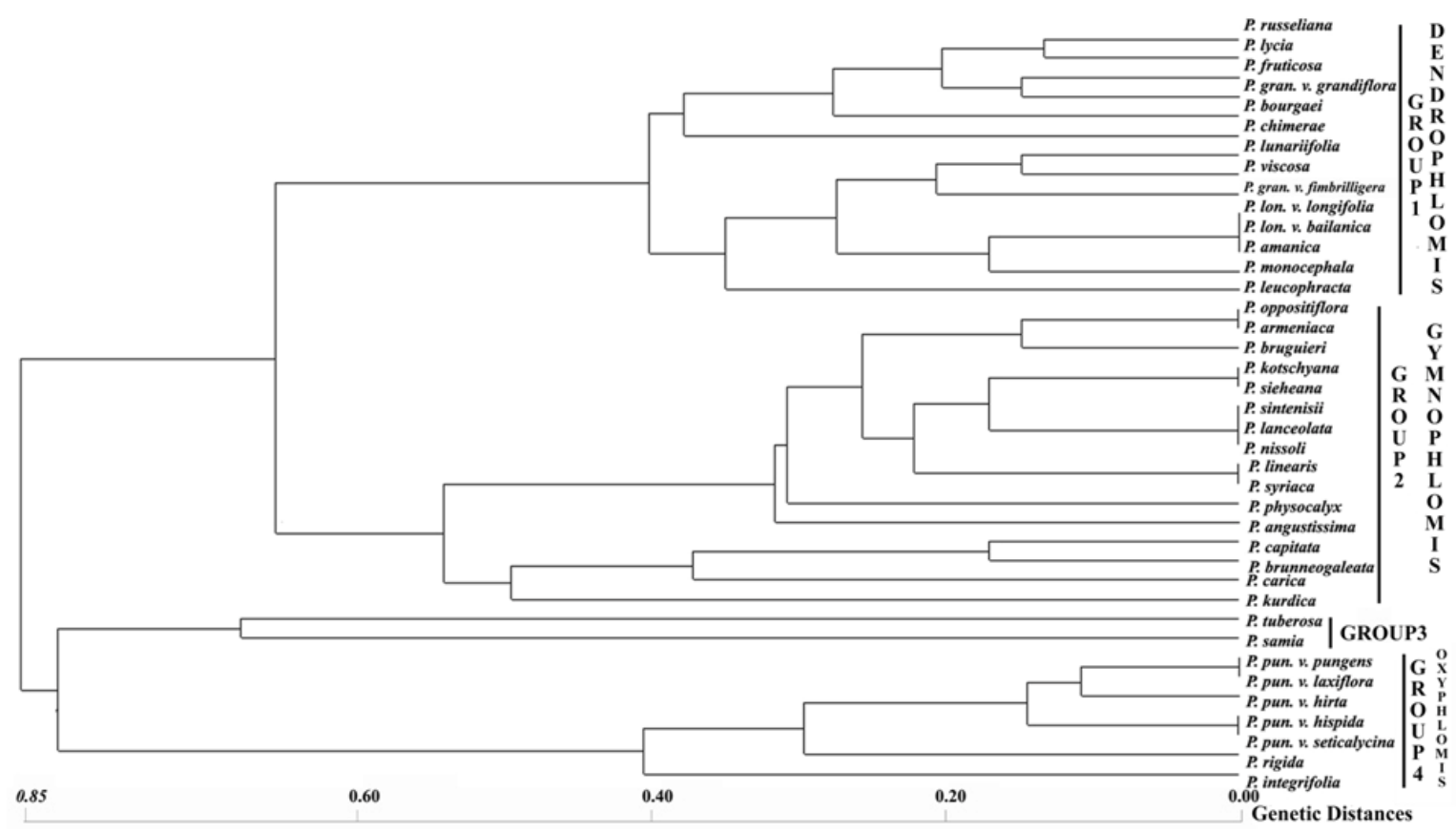

Figure 3. UPGMA dendrogram of 39 Phlomis taxa based on distances produced from Jaccard' similarity coefficients of seed storage proteins.

cover coding and non coding regions of DNA (Kirsten et al. 1998; Bussell et al. 2005). In addition to this, the different accessions sampled in the two studies, the different methods used for estimating genetic distances and the number of loci sampled in the two studies could be some other reasons of these differences.

The second group in the dendrogram comprised taxa from section Phlomis subsection Gymnophlomis: $P$. oppositiflora, P. armeniaca, P. bruguieri, $P$. kotschyana, $P$. sieheana, $P$. sintenisii, $P$. lanceolata, $P$. nissoli, P. linearis, $P$. syriaca, $P$. physocalyx, $P$. angustissima, $P$. capitata, $P$. brunneogaleata, $P$. carica and $P$. kurdica. Species in section Phlomis subsection Gymnophlomis are perennial herbs. In species of this subsection, bracteoles are weak and subulate to linear-lanceolate in shape, 6-12 in number and $0.5-10 \mathrm{~mm}$ in length, but they may be absent, as in $P$. oppositiflora or may reach up to $25 \mathrm{~mm}$, as in $P$. bruguieri (Azizian and Moore, 1982; Huber-Morath, 1982). Verticillasters are usually 4-8 flowered in these species and the number of verticillasters per stem is between 3 and 6 (Huber-Morath, 1982).

In the present study, no variability was observed between $P$. kotschyana and $P$. sieheana, between $P$. linearis and $P$. syriaca and among $P$. sintenisii, $P$. lanceolata and $P$. nissoli within subsection Gymnophlomis. In P. kotchyana and $P$. sieheana, bracteoles are $2-3 \mathrm{~mm}$ in length and leaves length is three times longer than their width in both species. On the other hand, the base of the basal and cauline leaves is cordate in $P$. kotschyana but cuneate or truncate in $P$. sieheana. The shapes of basal and cauline leaves are cordate to broadly triangular cordate in $P$. kotschyana but oblong to oblong-lanceolate in $P$. sieheana. In $P$. sintenisii, $P$. lanceolata and $P$. nissoli bracteoles are stellatetomentose and these species are also eglandular. Basal leaves are oblong to oblong-lanceolate in $P$. sintenisii and $P$. lanceolata but oblong to ovate in $P$. nissoli. Calyx teeth are lanceolate-acuminate in $P$. sintenisii and $P$. lanceolata but it is ovate-triangular in $P$. nissoli. P. linearis and $P$. syriaca are eglandular; their bracteoles are stellatetomentose and their calyx is slightly campanulate. The highest genetic distance was found between $P$. kurdica and $P$. physocalyx, with a genetic distance value of 0.625 within subsection Gymnophlomis in the present study (Table 2). While $P$. kurdica has either glandular or eglandular specimens, $P$. physocalyx has only eglandular specimens. The shape of the base of basal and cauline leaves is cordate in $P$. kurdica and cuneate in $P$. physocalyx. Number of flowers per verticillaster varies from 6 to 10 in $P$. kurdica and from 4 to 6 in $P$. physocalyx.

The third group included $P$. tuberosa from section Phlomoides and P. samia from section Phlomis subsection Oxyphlomis. P. tuberosa and P. samia have pink or purple corolla color in common. The fourth group contained taxa from section Phlomis subsection Oxyphlomis: P. pungens var. pungens, $P$. pungens var. laxiflora, $P$. pungens var. hirta, $P$. pungens var. hispida, $P$. pungens var. seticalycina, $P$. rigida and $P$. integrifolia. The shape of the base of $P$. tuberosa and $P$. samia is cordate-sagittate, but cuneate, truncate or obtuse in the species of the fourth group. Both 
P. tuberosa and P. samia have a branched single stem; however, species in the fourth group have many stem above the soil except for $P$. rigida, which has a single stem in generally, but a branched stem occasionally. Also, $P$. tuberose and $P$. samia have bigger cauline leaves than the species in the fourth group. In species of section Phlomis subsection Oxyphlomis bracteoles are rigid and subulate in shape; 9-40 in number and 10-26 mm in length (HuberMorath, 1982). Number of verticillasters in these species varies 2 to 6 in general (Huber-Morath, 1982). Within the fourth group, no protein variability was observed between $P$. pungens var. pungens and $P$. pungens var. laxiflora, and between $P$. pungens var. hispida and $P$. pungens var. seticalycina. Calyx teeth length is the only morphological diagnostic which discriminates $P$. pungens var. pungens from $P$. pungens var. laxiflora. Calyx teeth are $1 / 2$ as long as calyx tube or longer in var. pungens, but they are 1/3-1/5 as long as calyx tube in var. laxiflora (Huber-Morath, 1982). Morphological characters which differentiate $P$. pungens var. hispida from $P$. pungens var. seticalycina are adaxial suface of leaves and hairy structure on the stem. Adaxial surface of leaves is subglabrose in var. seticalycina but stellate-tomentose in var. hispida, and stem is covered with sparsely undivided hairs in var. seticalycina; however, in var. hispida it is covered with dense indumentum of undivided hairs, especially near nodes (Huber-Morath, 1982). P. samia was found to be the most distant species to both $P$. pungens var. pungens and $P$. pungens var. laxiflora, with a genetic distance value of 0.769 within the subsection Oxyphlomis in the present analysis (Table 2). While $P$. samia has glandular hairs on stem, leaves and the floral regions such as bracteoles and calyx, $P$. pungens is eglandular. The shape of the base of the cauline leaves is cordate in $P$. samia and cuneate in $P$. pungens. Flowers are shortly pedicellated in $P$. samia and sessile in $P$. pungens. Number of flowers per verticillaster varies from 10 to 18 in $P$. samia and from 6 to 10 in $P$. pungens. Calyx length varies from 8 to $18 \mathrm{~mm}$ in $P$. pungens and from 18 to 23 $\mathrm{mm}$ in P. samia.

In the present study, $P$. tuberosa, the only member of section Phlomoides in the Flora of Turkey, was expected to out group with the species of section Phlomis, but it clustered with subsection Oxyphlomis. This position of $P$. tuberosa could be understandable when considering that this species and species of subsection Oxyphlomis have pink or purple corolla color in common. Nevertheless, the inefficiency of section discrimination in the genus might be due to insufficient number of species sampled from section Phlomoides and thus, the number of species sampled from section Phlomoides need to be increased to examine whether the sectional division of the genus is supported by the SDS-PAGE analysis of seed proteins in future studies. On the other hand, the grouping pattern of the taxa in the present study supports the view of Huber-Morath (1982) in which section Phlomis was delimited in three subsections as Dendrophlomis, Gymnophlomis and Oxyphlomis. However, the taxa of subsection Gymnophlomis are grouped with the taxa of subsection Dendrophlomis in the dendrogram. This topology indicates that subsection Dendrophlomis is more closely related to subsection Gymnophlomis than subsection Oxyphlomis. This result is also in agreement with the morphological data that both subsections have yellow flower color in comparison to subsection Oxyphlomis that have purple or pink flower color. Overall, the results of the present study indicate that seed proteins in the genus Phlomis are useful characters to differentiate between species and to construct phylogenies for the assessment of evolutionary species relationships.

\section{ACKNOWLEDGMENTS}

The authors thank Sema Yuzbasioglu and Donna Sue Ozcan for correction of English.

\section{REFERENCES}

ALBALADEJO, R.G.; APARICIO, A. and SILVESTRE, S. Variation patterns in the Phlomis $x$ composite (Lamiaceae) hybrid complex in the Iberian Peninsula. Botanical Journal of Linnean Society, May 2004, vol. 145, no. 1, p. 97-108.

ALBALADEJO, Rafael G.; AGUILAR, Javier F.; APARICIO, Abelardo and FELINER, Gonzalo N. Contrasting nuclear-plastidial phylogenetic patterns in the recently diverged Iberian Phlomis crinita and P. lychnitis lineages (Lamiaceae). Taxon, November 2005, vol. 54, no. 4, p. 987-998.

ALBALADEJO, Rafael G. and APARICIO, Abelardo. Population genetic structure and hybridization patterns in the Mediterranean endemics Phlomis lychnitis and $P$. crinita (Lamiaceae). Annals of Botany, October 2007, vol. 100, no. 4, p. 735-746.

ALVAREZ, J.B.; MORAL, A. and MARTIN, L.M. Polymorphism and genetic diversity for the seed storage proteins in Spanish cultivated einkorn wheat (Triticum monococcum L. ssp. monococcum). Genetic Resources and Crop Evolution, August 2006, vol. 53, no. 5, p. 1061-1067.

AZIZIAN, D. and MOORE, D.M. Morphological and palynological studies in Phlomis L., Eromostachys Bunge and Paraphlomis Prain (Labiatae). Botanical Journal of Linnean Society, June 1982, vol. 85, p. 225-248.

BENTHAM, G. Labiatarum Genera et species. London, 1834, p. 323-644.

BHARGAVA, A.; RANA, T.S.; SHUKLA, S. and OHRI, D. Seed protein electrophoresis of some cultivated and wild species of Chenopodium. Biologia Plantarum, December 2005, vol. 49, no. 4, p. 505-511.

BUSSELL, John D.; WAYCOTT, Michelle and CHAPPILL Jennifer A. Arbitrarily amplified DNA markers as characters for phylogenetic inference. Perspectives in 
Plant Ecology, Evolution and Systematics, March 2005, vol. 7, no. 1, p. 3-26.

CHERDOUH, A.; KHELIFI, D.; CARRILLO, J.M. and NIETO-TALADRIZ, M.T. The high and low molecular weight glutenin subunit polymorphism of Algerian durum wheat landraces and old cultivars. Plant Breeding, August 2005, vol. 124, no. 4, p. 338-342.

FELSENSTEIN, J. PHYLIP (Phylogeny Inference Package) version 3.6a3. Distributed by the author. Seattle, Washington; Department of Genome Sciences, University of Washington, 2002.

GHAFOOR, Abdul; AHMAD, Zahoor; QURESHI, Afsari S. and BASHIR, Muhammad. Genetic relationship in Vigna mungo (L.) Hepper and V. radiata (L.) R. Wilczek based on morphological traits and SDS-PAGE. Euphytica, February 2002, vol. 123, no. 3, p. 367-378.

HEDGE, I.C. Labiatae of South-West Asia: diversity, distribution and endemism. Proceedings of the Royal Society of Edinburgh, 1986, vol. 89B, p. 23-35.

HUBER-MORATH, A. Phlomis L. In: DAVIS, P.H. ed. Flora of Turkey and East Aegean Island. Edinburgh; Edinburgh University Press, 1982, vol. 7, p. 102-126.

IGREJAS, G.; GUEDES-PINTO, H.; CARNIDE, V. and BRANLARD, G. Seed storage protein diversity in triticale varieties commonly grown in Portugal. Plant Breeding, 1999, vol. 118, no. 4, p. 303-306.

JHA, S.S. and OHRI, D. Comparative study of seed protein profiles in the genus Pisum. Biologia Plantarum, December 2002, vol. 45, no. 4, p. 529-532.

KARIHALOO, J.M.; KAUR, M. and SINGH, S. Seed protein diversity in Solanum melongena L. and its wild and weedy relatives. Genetic Resources and Crop Evolution, December 2002, vol. 49, no. 6, p. 533-539.

KIRSTEN, Janet H.; DAWES, Clinton J. and COCHRANE, Bruce J. Randomly amplified polymorphism detection (RAPD) reveals high genetic diversity in Thalassia testudinum banks ex König (Turtlegrass). Aquatic Botany, August 1998, vol. 61, no. 4, p. 269-287.

LAEMMLI, U.K. Cleavage of structural proteins during the assembly of the head of bacteriophage T4. Nature, August 1970, vol. 227, no. 5259, p. 680-685.

MIRALI, N.; EL-KHOURI, S. and RIZQ, F. Genetic diversity and relationships in some Vicia species as determined by SDS-PAGE of seed proteins. Biologia Plantarum, December 2007, vol. 51, no. 4, p. 660-666.

MOENCH, Conrad. Methodus plantas Horti botanici et agri Marburgensis, a straminum situ describendi. Marburgi Cattorum, Marburg, Germany. 1794.
OLIVIERI, Enna; HERBERT, Ben and RİGHETTİ, Pier Giorgio. The effect of protease inhibitors on the two dimensional electrophoresis pattern of red blood cell membranes. Electrophoresis, February 2001, vol. 22, no. 3, p. $560-565$

PANIGRAHI, J.; KUMAR, D.R.; MISHRA, M.; MISHRA, R.P. and JENA, P. Genomic relationships among 11 species in the genus Cajanus as revealed by seed protein (albumin and globulin) polymorphisms. Plant Biotechnology Reports, April 2007, vol. 1, no. 2, p. 109-116.

RAMAGLI, Louis S. and RODRIGUEZ, Lewis V. Quantitation of microgram amounts of protein in two dimensional polyacrylamide gel electrophoresis sample buffer. Electrophoresis, April 1985, vol. 6, no. 11, p. 559563.

ROHLF, F.J. NTSYS-pc numerical taxonomy and multivariate analysis system version 1.7. New York; Exeter Publications, 1992.

ROUT, Anusuya and CHRUNGOO, Nikhil K. Genetic variation and species relationships in Himalayan buckwheats as revealed by SDS-PAGE of endosperm proteins extracted from single seeds and RAPD based DNA fingerprints. Genetic Resources and Crop Evolution, June 2007, vol. 54, no. 4, p. 767-777.

STOILOVA, T.; CHOLAKOVA, N. and MARKOVA, M. Variation in seed protein and isoenzyme patterns in Cucurbita cultivars. Biologia Plantarum, September 2006, vol. 50, no. 3, p. 450-452.

SYROS, T.; YUPSANIS, T. and ECONOMOU, A. Fractionation and electrophoretic patterns of storage proteins of Ebenus cretica. A preliminary survey as a tool in taxonomy. Biologia Plantarum, April 2003, vol. 46, no. 3, p. 435-443.

TAYLOR, J.M. Phlomis, the neglected genus, a guide for gardeners and horticulturists. National Council for the Conservation of Plants and Gardens, Westbury-on-severn; Gloucester, England, 1998, p. 3-87. ISBN 0953241300.

YUZBASIOGLU, E.; ACİ, L. and OZCAN, S. Seed protein diversity among lentil cultivars. Biologia Plantarum, March 2008a, vol. 52, no. 1, p. 126-128.

YUZBASIOGLU, Ertugrul; DADANDI, Mehmet Y. and OZCAN, Sebahattin. Natural hybridization between Phlomis lycia D. Don x P. bourgaei Boiss. (Lamiaceae) revealed by RAPD markers. Genetica, May 2008b, vol. 133, no. 1, p. 13-20.

YUZBASIOGLU, Ertugrul and DADANDI, Mehmet Y. Phylogenetic relationships among species of the subsection Dendrophlomis Bentham. Electronic Journal of Biotechnology, October 2008, vol.11, no. 4. 
VLADOVA, R.; PANDEVA, R. and PETCOLICHEVA, K.

Seed storage proteins in Capsicum annuum cultivars.

Biologia Plantarum, August 2000, vol. 43, no. 2, p. 291-

295. 